\title{
HUMORAL IMMUNE RESPONSE TO MEASLES, VARICELLA-ZOSTER AND TETANUS VACCINATION IN PRETERM INFANTS
}

\author{
C.F. Schlindwein, M.C.A.A. Perin, M.I. de Moraes-Pinto, R. Simão, A.F.M.A. Mimica, L.Y. Weckx, A.L. \\ Goulart, A.M.N. dos Santos \\ Department of Pediatrics/ Neonatal Division of Medicine, Federal University of São Paulo (UNIFESP), São \\ Paulo, Brazil
}

Background and aims: Antibody response may be lower in preterm infants. This study aimed to compare the immune response to vaccination against measles, varicella and tetanus in preterm and term infants and to analyze factors associated with antibody level.

Methods: Two prospective cohorts of infants aged 12-18 months; Group 1: Very low birth-weight preterm infants; Group 2: Term infants. Antibodies were measured before and after vaccination against measles at $12 \mathrm{mo}$ and tetanus booster and varicella at $15 \mathrm{mo}$. Comparisons were performed by t-test or $\mathrm{x}^{2}$. Factors associated with antibody levels were analyzed by linear regression, considering $\mathrm{p}<0.05$ significant.

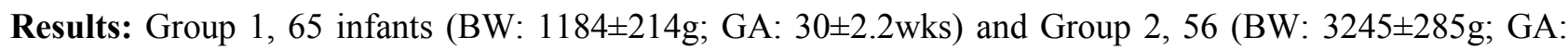
$39 \pm 1 \mathrm{wks})$ were similar regarding proportion of infants with protective antibody levels against measles $(>0.12 \mathrm{IU} / \mathrm{mL})$, varicella $(\geq 0.1 \mathrm{IU} / \mathrm{mL})$ and tetanus $(\geq 0.1 \mathrm{IU} / \mathrm{mL})$. Antibody levels before and after vaccination were similar in both groups for measles $(0.026$ vs. $0.027 ; 2.394$ vs. 2.412$)$, varicella $(0.044$ vs. $0.05 ; 0.353$ vs. 0.317$)$ and tetanus $(0.147$ vs. $0.205 ; 1.997$ vs. 1.740$)$. By linear regression, being premature decreased tetanus antibody titers in $-0.106(\mathrm{p}=0.023)$ and an increase in $1 \mathrm{wk}$ in GA raised tetanus antibody titers in 0.012 at $15 \mathrm{mo}(\mathrm{p}=0.032)$. Regarding to varicella, an increase in $1 \mathrm{wk}$ in GA raised antibody titers in 0.015 at $15 \mathrm{mo}(\mathrm{p}=0.030)$.

Conclusions: Humoral immune responses were similar in both groups. Greater GA was associated with increased antibody levels against tetanus and varicella.

\section{Supported by FAPESP, Brazil}

